\title{
Pelestarian Koleksi Langka Berbasis Flipbook di Perpustakaan Umum
}

\author{
Ifon Margiati Rahayu* \\ Dinas Kearsipan dan Perpustakaan Kabupaten Banjarnegara, Indonesia
}

\section{Abstract}

Introduction. Currently, the office limits access to collections of rare books for users to preserve the physical collection. Users who want to access the display will only get a synopsis. However, this policy makes users challenging to access the full-text content.

Paper type:

Research article

Article history:

Received April 1, 2021

Revised November 8, 2021

Accepted November 8, 2021

Keywords:

- Preservation

- rare book collection

- digitalization

- flipbook
The collection of rare books has also not received proper preservation and creates some rare book collections to be damaged. This study aims to determine the process of digitizing the rare book collections at the Archives and Library Office of Banjarnegara Regency based on Flipbook.

Methodology. This study is a qualitative descriptive study. The selection of informants in this study is a purposive sampling technique. The data collection in this study is observation, interview, and literature study.

Result and discussion. This study shows that digitizing the rare book collections includes selection, scanning, editing, flipbook making, and uploading on the OPAC INLISLite application 3.1. Users can access rare book collections in the form of flipbooks or interesting digital books. The obstacles found in digitizing rare book collections are the absence of SOPs of digitizing, inadequate digitization facilities and infrastructures, the absence of Human Resources (HR). Nevertheless, they master the digitization of collections and the lack of budget allocations for digitizing the collection.

Conclusion. The impact of digitization with Flipbook is that users have full access to a collection of rare books needed by users and become an alternative to the preservation and empowerment of libraries and users that are more attractive and safe.

\section{Pendahuluan}

Perpustakaan adalah salah satu unit atau lembaga yang mengelola informasi dan bertugas melakukan pengumpulan, pengolahan, penyajian dan perawatan koleksi agar dapat dimanfaatkan oleh pemustaka dalam rentang waktu yang cukup lama secara efektif dan efisien. Informasi yang terkandung di dalam koleksi perlu dirawat dan dilestarikan agar dapat diwariskan kepada generasi yang akan datang. Kemajuan teknologi membuat masyarakat menginginkan kemudahan dalam mengakses informasi secara terbuka, mudah dan cepat. Begitu juga dengan perpustakaan dalam paradigma lamanya terdiri dari rak-rak yang berisi kumpulan buku-buku harus bertransformasi dengan melakukan digitalisasi koleksi. Selain itu, pemustaka milenial membuat tingginya penetrasi internet, infrastruktur digital, dan aksesibilitas, sehingga membuat perpustakaan perlu melakukan kegiatan digitalisasi. Perpustakaan juga harus mampu bersaing dengan kecanggihan teknologi informasi dengan cara menyediakan koleksi dalam bentuk digital, di mana pemustaka bisa mengakses koleksi perpustakaan dari jarak jauh dan dalam bentuk elektronik.

\footnotetext{
* Corresponding author.

Email address: ivone.margiati@gmail.com (I. M. Rahayu)
} 
Koleksi digital merupakan suatu publikasi berupa teks dan gambar dalam bentuk digital yang diproduksi, diterbitkan dan dapat dibaca melalui komputer atau alat digital lainnya (Andina, 2011). Koleksi digital banyak digandrungi oleh perpustakaan dan pengguna karena menghemat ruangan, multiple access, tidak terbatas ruang dan waktu, dapat berbentuk multimedia, dan biaya lebih murah (Saleh, 2013). Koleksi digital saat ini juga sudah banyak ditemukan, antara lain koleksi digital yang tersedia dalam aplikasi "Perpustakaan Daerah Kabupaten Banjarnegara" yang diselenggarakan oleh Dinas Kearsipan dan Perpustakaan Kabupaten Banjarnegara bekerjasama dengan PT. Enam Kubuku Indonesia. Pemustaka dapat membaca koleksi tersebut dengan menggunakan aplikasi berbasis android maupun versi windows. Untuk versi $O S$ Android bisa diunduh di play store menggunakan perangkat PC, tablet maupun smartphone.

Dinas Kearsipan dan Perpustakaan Kabupaten Banjarnegara sudah memiliki koleksi digital sebanyak 956 judul dengan 2.429 eksemplar, namun Dinas Kearsipan dan Perpustakaan Kabupaten Banjarnegara belum mengalihmediakan koleksi buku langka, padahal koleksi buku langka sangat memerlukan pelestarian, mengingat kondisi fisik buku yang semakin rapuh. Selama ini akses koleksi buku langka di Dinas Kearsipan dan Perpustakaan Kabupaten Banjarnegara masih terbatas yaitu hanya bisa membaca sinopsisnya saja tanpa menyentuh koleksi buku tersebut. Hal ini bertujuan untuk menjaga kondisi fisik koleksi dan nilai yang terkandung di dalamnya.

Koleksi buku langka di Dinas Kearsipan dan Perpustakaan Kabupaten Banjarnegara belum mendapatkan perawatan khusus dan disimpan dalam rak kaca. Hal ini membuat koleksi buku langka mengalami kerusakan seperti kertas mulai rapuh, kertas dimakan rayap, berubah warna menjadi coklat, dan tinta mulai memudar. Untuk memulai antisipasi hal tersebut, maka perlu dilakukan digitalisasi koleksi buku langka dari cetak ke digital dalam suatu bentuk sebagai upaya pelestarian.

Kini, terdapat desain tampilan buku digital yang banyak diminati masyarakat yaitu buku digital dengan teknologi e-book tiga dimensi yang dikenal dengan istilah flipbook, di mana seseorang seperti membaca buku asli di layar monitor (Riyanto et al., 2012). Kelebihan flipbook dapat menyajikan perpaduan materi dalam bentuk kata-kata, kalimat, gambar, suara bahkan video yang dilengkapi dengan beragam warna, sehingga lebih menarik perhatian, pembuatannya mudah, harganya murah, mudah diakses, dan dapat meningkatkan aktivitas membaca (Susilana \& Riyana, 2008). Berbeda dengan buku digital dalam bentuk PDF, tampilan flipbook jauh lebih menarik walaupun flipbook tetap memiliki kelemahan, yakni ketergantungan pada sumber daya listrik dan kebutuhan perangkat dengan spesifikasi cukup tinggi untuk menampilkan flipbook, karena perpaduan fitur yang beragam (Ulandari et al., 2018).

Pengembangan koleksi buku langka dalam bentuk flipbook di Dinas Kearsipan dan Perpustakaan Kabupaten Banjarnegara perlu diwujudkan. Untuk itu, kajian ini ingin melihat proses digitalisasi koleksi buku langka berbasis flipbook di Dinas Kearsipan dan Perpustakaan Kabupaten Banjarnegara. Pengembangan tersebut diharapkan dapat menjadi upaya pelestarian yang lebih efisien dan efektif. Dengan adanya koleksi buku langka dalam bentuk buku digital akan mempermudah akses pemustaka yang ingin membaca koleksi tersebut di Dinas Kearsipan dan Perpustakaan Kabupaten Banjarnegara secara full-text. 


\section{Tinjauan Pustaka}

\subsection{Pelestarian Bahan Pustaka}

Menurut Kamus Besar Bahasa Indonesia (Departemen Pendidikan Nasional, 2014), pelestarian berasal dari kata lestari yang berarti tetap selama-lamanya tidak berubah. Pelestarian adalah kegiatan yang bertujuan memperpanjang umur bahan pustaka dan informasi yang terdiri dari dua aspek yaitu pelestarian fisik dokumen dan pelestarian terhadap informasi yang terkandung di dalamnya (Sulistyo-Basuki, 1991). Jadi pelestarian bahan pustaka adalah upaya untuk memperpanjang umur keterpakaian bahan pustaka dan informasi, sehingga dapat dimanfaatkan oleh pemustaka dalam waktu yang lebih lama.

Menurut Martoatmodjo (2013) tujuan pelestarian antara lain, (1) menyelamatkan nilai informasi dokumen, dalam kegiatan pelestarian penyelamatan nilai informasi dokumen menjadi tujuan yang utama agar dapat dimanfaatkan dalam waktu yang relatif lebih lama dan terhindar dari kerusakan; (2) menyelamatkan fisik dokumen, dengan adanya pelestarian koleksi maka diharapkan kondisi fisik dokumen tetap terjaga keutuhannya. Pemustaka bisa mengakses informasi yang diinginkan dalam bentuk digital; (3) mengatasi kendala kekurangan ruang, pelestarian membuat koleksi menjadi lebih awet dan bisa dipakai lebih lama, sehingga akan mengurangi penambahan koleksi yang di sebabkan karena kerusakan; (4) mempercepat perolehan informasi, pelestarian dalam bentuk digital akan lebih memudahkan pemustaka dalam mengakses informasi yang terkandung dalam sebuah koleksi seperti DVD, CD-ROM, MS Word, PDF, CD (Compact Disk), koleksi dalam bentuk flipbook dan media penyimpanan digital lainnya baik dari jarak jauh maupun jarak dekat.

Pelestarian juga meliputi kegiatan memelihara dan mengawetkan bahan pustaka dengan tujuan supaya bahan pustaka dalam kondisi yang baik dan siap dilayankan kepada pemustaka. Peran pustakawan di sinilah dibutuhkan dengan dibekali pengetahuan dan keterampilan dalam melestarikan koleksi perpustakaan.

\subsection{Koleksi Buku Langka}

Menurut Peraturan Perpustakaan Nasional Republik Indonesia Nomor 2 (2019), koleksi langka yaitu koleksi yang dimiliki oleh perpustakaan yang mempunyai nilai informasi tinggi dan keberadaannya sangat terbatas, sedangkan Susanto Zuhdi dalam Asaniyah (2017) menyatakan bahwa koleksi langka adalah koleksi yang sudah tidak diterbitkan lagi meskipun koleksi tersebut merupakan koleksi baru dan usianya belum terlalu lama. Jadi koleksi langka adalah koleksi bernilai tinggi yang sulit ditemukan karena sudah tidak diterbitkan lagi di pasaran serta jumlah eksemplar koleksi yang terbatas. Oleh sebab itu koleksi buku langka perlu dilakukan digitalisasi sehingga bisa dimanfaatkan secara maksimal. Digitalisasi koleksi buku langka juga harus menjaga dan melindungi hak cipta seseorang. Menurut Undang-undang RI No 28 Tahun 2014 tentang Hak Cipta (2014), masa berlaku hak cipta suatu karya berupa buku adalah selama hidup penciptanya dan terus berlangsung selama 70 tahun sesudah penciptanya meninggal dunia, sedangkan menurut Asaniyah (2017) menyebutkan ada beberapa kriteria buku langka yaitu: (1) buku baru yang dicetak dengan jumlah terbatas; (2) buku terbitan lama dan sudah berumur puluhan bahkan ratusan tahun yang memiliki nilai sejarah terkait tokoh penting pada zamannya atau peristiwa penting pada masa lalu; dan (3) buku favorit pada masa penerbitannya dan sekarang sudah tidak diterbitkan lagi. 
Koleksi buku langka biasanya mengandung informasi yang sangat bernilai, sehingga sebagian perpustakaan akan menyimpan di tempat atau rak khusus yang aman. Karakteristik dari koleksi buku langka itu sendiri adalah unik seperti jumlah yang sangat terbatas, koleksi yang sudah tidak diterbitkan lagi, koleksi dengan ejaan zaman dahulu, bentuk buku yang kuno dan memiliki nilai sejarah. Karakteristik inilah yang seharusnya membuat perpustakaan memberikan perawatan yang khusus dan pelayanan yang modern mengikuti perkembangan zaman salah satunya dengan cara digitalisasi koleksi.

\subsection{Digitalisasi Koleksi}

Alih media informasi erat kaitannya dengan istilah digitalisasi. Menurut Hs. (2009) digitalisasi adalah proses alih media dari bentuk tercetak menjadi bentuk elektronik. Dalam pelaksanaan digitalisasi suatu perpustakaan harus memiliki kebijakan atau aturan terkait koleksi apa saja yang perlu dialihmediakan. Salah satu koleksi perpustakaan yang perlu dilakukan digitalisasi yaitu koleksi buku langka karena koleksi ini memiliki nilai sejarah yang perlu dilestarikan. Beberapa pertimbangan suatu perpustakaan dalam melakukan kegiatan digitalisasi koleksi antara lain yaitu kekuatan koleksi, keunikan koleksi, prioritas bagi komunitas pengguna, kemampuan staf, kekuatan koleksi dan keunikan koleksi (Surachman, 2007). Pertimbangan dalam pemilihan koleksi yang akan dilakukan digitalisasi meliputi (1) Sejarah dan/atau kebudayaan serta koleksi yang mengandung muatan lokal; (2) koleksi yang bersifat unik dan/atau koleksi langka; (3) koleksi yang sering dicari oleh pemustaka; (4) koleksi yang sudah tidak memiliki hak cipta, dan/atau sudah memiliki ijin dari pengarangnya untuk dilakukan digitalisasi; (5) pembatasan akses ke koleksi aslinya dengan pertimbangan demi menjaga keutuhan fisik koleksi, memiliki nilai historis yang tinggi serta kerentanan atau lokasi; dan (6) memberikan kemudahan kepada masyarakat untuk mengakses secara online (Perpustakaan Nasional RI, 2014).

Pelaksanaan digitalisasi koleksi buku langka memiliki beberapa kendala (Asaniyah, 2017).

\subsubsection{Anggaran Besar}

Ketersediaan anggaran menjadi tantangan dan salah satu kendala bagi suatu perpustakaan dalam kegiatan digitalisasi. Kegiatan ini membutuhkan dana awal yang tidak sedikit terutama untuk mempersiapkan peralatan yang digunakan seperti pembelian komputer, scanner, jaringan listrik, pelatihan staf dan sebagainya. Pimpinan membutuhkan pertimbangan yang matang dalam mengalokasikan anggaran. Untuk itu perpustakaan harus membuat skala prioritas tentang kegiatan apa saja yang akan dilaksanakan. Di samping itu diperlukan tahapan sedikit demi sedikit untuk melakukan digitalisasi secara bertahap sesuai dengan jenis koleksi yang menjadi prioritas utama.

\subsubsection{Sumber Daya Manusia (SDM)}

Belum semua perpustakaan memiliki pustakawan atau pengelola perpustakaan yang menguasai digitalisasi koleksi. Pustakawan atau pengelola perpustakaan belum memiliki pendidikan khusus, serta kurangnya kesadaran akan pentingnya pelestarian informasi yang terkandung dalam buku langka. 


\subsubsection{Tingkat Kerusakan}

Kondisi fisik buku langka yang tidak sama membutuhkan penanganan yang berbeda. Diperlukan penanganan pustakawan atau pengelola perpustakaan yang mumpuni dalam mengerjakan digitalisasi agar koleksi buku langka tidak semakin rusak.

\subsubsection{Peralatan}

Proses digitalisasi rentan mengalami kerusakan, seperti halnya sistem komputer yang bisa terserang virus komputer, maka diperlukan teknisi yang harus siap dan sering melakukan pengecekan pada peralatan dan sistem yang digunakan dalam proses digitalisasi.

Terdapat beberapa manfaat digitalisasi bahan pustaka (Fadhlullah \& Christiani, 2019) yaitu: (1) akses. Adanya digitalisasi bahan pustaka akan memungkinkan akses yang lebih besar terhadap koleksi yang berbentuk digital; (2) mendukung preservasi. Digitalisasi koleksi merupakan upaya pelestarian bahan pustaka supaya menjaga keutuhan fisik dokumen dan informasi yang terkandung di dalamnya. Hasil digitalisasi koleksi merupakan pengganti bahan pustaka yang sudah rusak atau rapuh yang bisa diakses oleh pemustaka; (3) pengembangan koleksi. Kegiatan digitalisasi koleksi dapat mengatasi kesenjangan koleksi bahan pustaka. Ketika dilakukan digitalisasi koleksi maka dapat memberikan kesempatan untuk menyatukan kembali koleksi yang terpisah, dan secara virtual koleksi perpustakaan tersebut dapat disatukan kembali; (4) manfaat bagi instansi. Kegiatan digitalisasi koleksi dapat meningkatkan profil suatu institusi. Selain bertujuan untuk melestarikan bahan pustaka yang bernilai tinggi, digitalisasi juga dapat meningkatkan prestige dan nilai lebih bagi sebuah institusi; (5) penelitian dan pendidikan. Manfaat digitalisasi koleksi warisan budaya dapat bermanfaat bagi pendidikan yang menyajikan berbagai modul materi pada situs website. Dengan memanfaatkan kecanggihan teknologi akan mendukung di bidang sektor pendidikan untuk menyebarluaskan berbagai sumber daya pendidikan kepada masyarakat. Digitalisasi koleksi akan membantu di bidang sektor pendidikan dan penelitian. Peneliti akan lebih mudah mengakses koleksi baik dari jarak jauh maupun jarak dekat untuk memperoleh informasi yang diinginkan.

Digitalisasi memiliki beberapa persiapan yang harus dilakukan. Sebelum melakukan digitalisasi koleksi, dilakukan pengecekan kondisi fisik bahan pustaka untuk memastikan kondisi fisik bahan pustaka tersebut di antaranya apakah rapuh, berlubang, halamannya komplit atau tidak dan lain-lain. Dalam artikel ini peneliti khusus membahas mengenai Digitalisasi Koleksi Buku Langka sebagai Upaya Pelestarian Bahan Pustaka di Dinas Kearsipan dan Perpustakaan Kabupaten Banjarnegara.

\subsection{Flipbook}

Flipbook merupakan buku digital dengan teknologi e-book tiga dimensi, di mana halaman buku bisa dibuka seperti membaca buku pada layar monitor dengan cara mengklik tombol pada layar monitor ketika akan membuka halaman berikutnya (Riyanto et al., 2012). Pembuatan flipbook dilakukan dengan menggunakan software flipbook maker yaitu software yang digunakan untuk membuat tampilan buku atau bahan ajar lainnya menjadi seperti sebuah buku elektronik digital berbentuk flipbook(Sugianto et al., 2013). Produk akhir dari kegiatan digitalisasi koleksi buku langka di Dinas Kearsipan dan Perpustakaan Kabupaten Banjarnegara adalah koleksi buku langka dalam bentuk flipbook yang bisa diakses pada OPAC (Online Public Acces Catalogue) aplikasi INLISLite versi 3.1 
secara full-text. Tampilan flipbook akan menarik dan tidak membosankan sehingga diharapkan bisa meningkatkan minat baca pemustaka yang ingin mengakses koleksi buku langka.

Bahwa sebelumnya juga ada penelitian terdahulu yang dilakukan oleh Putranto \& Husna (2015) mengenai digitalisasi koleksi dengan judul "Proses Digitalisasi Koleksi Deposit di UPT Perpustakaan Daerah Provinsi Jawa Tengah". Penelitian terdahulu berguna untuk mengetahui bagaimana metode penelitian dan hasil penelitian yang dilakukan. Penelitian terdahulu juga digunakan sebagai tolak ukur peneliti untuk menulis dan menganalisis suatu penelitian. Perbedaan dari penelitian yang terdahulu dengan penelitian ini adalah pada objek, tahapan digitalisasi dan produk akhir hasil digitalisasi. Jika penelitian terdahulu melakukan digitalisasi terhadap koleksi deposit, maka penelitian sekarang melakukan digitalisasi terhadap koleksi buku langka. Pengemasan pada penelitian sebelumnya berbentuk $C D$ dan data digital yang disimpan di server, sedangkan hasil akhir digitalisasi yang sekarang, berbentuk flipbook dan bisa diakses pada OPAC aplikasi INLISLite versi 3.1.

\section{Metode Penelitian}

Metode penelitian mengenai digitalisasi koleksi buku langka sebagai upaya pelestarian bahan pustaka di Dinas Kearsipan dan Perpustakaan Kabupaten Banjarnegara menggunakan metode pendekatan deskriptif kualitatif. Penelitian deskriptif adalah mengumpulkan data berdasarkan faktor- faktor yang menjadi pendukung terhadap objek penelitian, kemudian menganalisa faktor- faktor tersebut untuk dicari peranannya. Sedangkan penelitian kualitatif merupakan penelitian yang berhubungan dengan ide, persepsi, pendapat, kepercayaan orang yang akan diteliti dan kesemuanya tidak dapat diukur dengan angka. Teori yang digunakan dalam penelitian ini tidak dipaksakan untuk memperoleh gambaran seutuhnya mengenai suatu hal menurut pandangan manusia yang telah diteliti (Sulistyo-Basuki, 2006). Metode pendekatan deskriptif kualitatif adalah metode pengolahan data dengan cara menganalisa faktor-faktor yang berkaitan dengan objek penelitian dengan penyajian data secara lebih mendalam terhadap objek penelitian (Prabowo \& Heriyanto, 2013).

Pemilihan informan dalam penelitian ini menggunakan teknik purposive sampling yaitu teknik penentuan informan dengan berdasarkan kriteria atau pertimbangan tertentu. Kriteria dalam penelitian ini adalah informan harus pustakawan di Dinas Kearsipan dan Perpustakaan Kabupaten Banjarnegara. Informan pernah melakukan kegiatan digitalisasi koleksi buku langka. Peneliti juga menambahkan informan pendukung yaitu pemustaka yang pernah membaca koleksi digital buku langka dalam bentuk flipbook di Dinas Kearsipan dan Perpustakaan Kabupaten Banjarnegara. Peneliti melakukan wawancara kepada pustakawan dan pemustaka tanpa adanya paksaan dengan menanyakan mengenai digitalisasi koleksi buku langka di Dinas Kearsipan dan Perpustakaan Kabupaten Banjarnegara.

\section{Hasil dan Pembahasan}

Digitalisasi koleksi buku langka tergolong sangat jarang dilakukan perpustakaan. Biasanya perpustakaan hanya mengalihmediakan karya ilmiah seperti tugas akhir, skripsi, tesis, disertasi, atau koleksi buku karena koleksi buku langka banyak luput dari perhatian pengelola perpustakaan atau pustakawan. Digitalisasi merupakan salah satu kegiatan untuk melestarikan khasanah budaya bangsa dengan cara mengalihbentukkan dari bentuk 
asli (document printed) ke dalam bentuk digital. Tujuan digitalisasi koleksi buku langka yaitu agar koleksi tetap terjaga nilai informasi dan kondisi fisiknya, sehingga dapat dimanfaatkan oleh pemustaka dalam jangka waktu yang lebih lama. Digitalisasi koleksi buku langka dilakukan dengan cara mengalihmediakan isi kandungan koleksi ke media lain yaitu dari bentuk tercetak ke dalam bentuk softfile. Digitalisasi koleksi sebaiknya dilakukan oleh orang yang memiliki keahlian di bidangnya, sehingga dapat dilakukan dengan baik, produktif dan dapat mewujudkan tujuan dilakukannya digitalisasi koleksi (Asaniyah, 2017).

Produk akhir dari digitalisasi koleksi buku langka di Dinas Kearsipan dan Perpustakaan Kabupaten Banjarnegara yaitu koleksi digital berbentuk flipbook yang bisa diakses pada OPAC aplikasi INLISLite versi 3.1, sedangkan INLISLite adalah perangkat lunak (software) aplikasi otomasi perpustakaan yang dibangun dan dikembangkan oleh Perpustakaan Nasional RI. Dinas Kearsipan dan Perpustakaan Kabupaten Banjarnegara menggunakan aplikasi ini untuk semua kegiatan di bidang perpustakaan seperti pengolahan dan pelayanan.

\subsection{Peralatan Digitalisasi Koleksi Buku Langka}

Kegiatan digitalisasi koleksi buku langka di Dinas Kearsipan dan Perpustakaan Kabupaten Banjarnegara menggunakan alat yang sesuai dengan kebutuhan dan kegunaanya. Peralatan yang diperlukan adalah perangkat keras dan perangkat lunak. Perangkat keras yang dibutuhkan yaitu komputer/laptop, scanner dan server. Scanner yang digunakan pada tipe flatbed dengan merk Canon dan scanner tipe overhead ScanSnap SV600, sedangkan perangkat lunak yang diperlukan yaitu (1) aplikasi CanoScan LiDe 120 untuk scanner tipe flatbed. Aplikasi ini digunakan untuk scanning koleksi buku langka yang kondisinya masih baik atau belum rapuh. Proses scan menggunakan scanner ini dengan cara membuka halaman koleksi buku langka satu per satu; (2) aplikasi ScanSnap Manager untuk scanner tipe overhead. Aplikasi ini digunakan untuk scanning koleksi buku langka yang sudah rapuh. Scanner tipe overhead ini tidak merusak koleksi karena proses scanning dengan cara meletakkan buku dan tinggal di scan, (3) aplikasi Nitro Pro 9 untuk mengolah hasil scanning dan melakukan editing seperti mengecek hasil scanning, combine file hasil scanning dan membuat watermark sebagai identitas koleksi; (5) aplikasi 3D Page Flip Standard untuk membuat hasil scanning menjadi bentuk flipbook yang menarik; dan (6) aplikasi INLISLite versi 3.1 sebagai aplikasi yang digunakan untuk menampilkan koleksi digital dalam bentuk flipbook.

\subsection{Sumber Daya Manusia}

Peran sumber daya manusia sangat perlu diperhatikan dalam kegiatan digitalisasi, dan semua harus dipersiapkan dari awal pada tahap perencanaan. Kegiatan digitalisasi koleksi langka di Dinas Kearsipan dan Perpustakaan Kabupaten Banjarnegara dilakukan oleh pustakawan yang pernah melakukan kegiatan digitalisasi koleksi dan memahami prosedur serta tahapan digitalisasi. Pustakawan melakukan pemilihan prioritas koleksi yang akan di digitalisasi, pengecekan kondisi koleksi, scaning koleksi, editing, publishing, mengelola informasi digital, membuat panduan untuk pemustaka bagaimana cara menggunakan layanan koleksi digital. 


\subsection{Proses Digitalisasi Koleksi Buku Langka}

Sebelum dilakukan proses digitalisasi koleksi buku langka, perlu dilakukan seleksi terhadap koleksi buku langka untuk menentukan mana yang membutuhkan penanganan terlebih dahulu serta memprioritaskan kondisi fisik dan nilai yang terkandung di dalamnya. Setelah menyeleksi koleksi, langkah selanjutnya adalah mengidentifikasi atau mengecek kondisi koleksi buku langka berdasarkan kondisi fisiknya. Apakah kertas dari koleksi buku langka tersebut rapuh, robek, halaman hilang, berwarna kuning, berlubang dan sebagainya. Hal ini dilakukan untuk menentukan alat yang sesuai dengan kondisi buku langka dan mempermudah proses digitalisasi. Jika koleksi dalam keadaan rapuh, maka menggunakan scanner overhead(lihat Gambar 1). Scanner overhead adalah scanner yang memiliki fungsi untuk memindai dokumen hingga buku tanpa harus menekan koleksi seperti pada proses scanning menggunakan scanner tipe flatbed. Sedangkan untuk koleksi yang kondisi fisiknya masih baik maka menggunakan scanner tipe flatbed (lihat Gambar 2). Proses scanning dengan menggunakan scanner overhead dan tipe flatbed adalah sama yaitu koleksi di scan setiap halaman sampai selesai dan disimpan dalam bentuk file PDF. Perbedaannya adalah software aplikasi untuk scanner overhead menggunakan aplikasi Scan Snap Manager sedangkan scanner tipe flatbed mengggunakan Cano Scan LiDe 120.

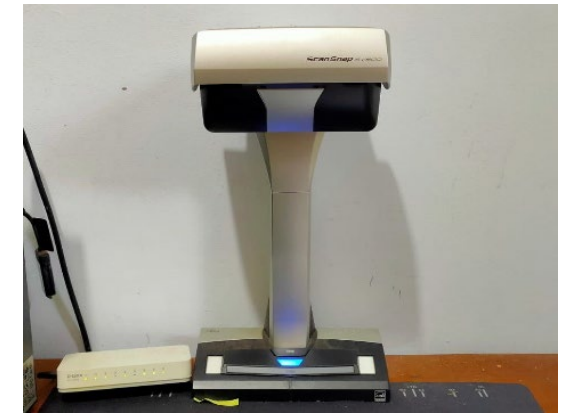

Gambar 1. Scanner Overhead

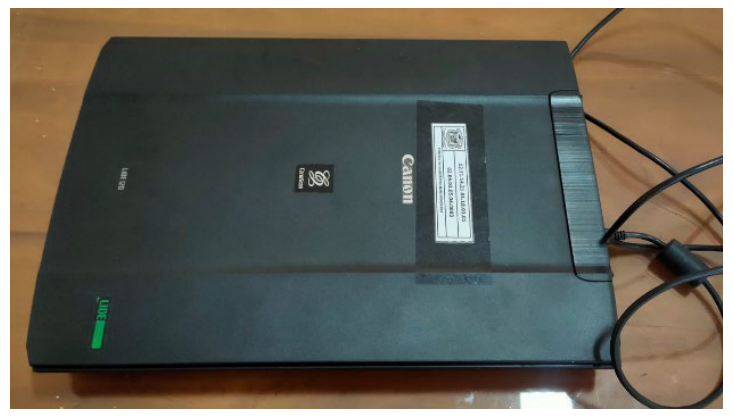

Gambar 2. Scanner Tipe flatbed

(Sumber: Dinas Kearsipan dan Perpustakaan Kab. Banjarnegara)

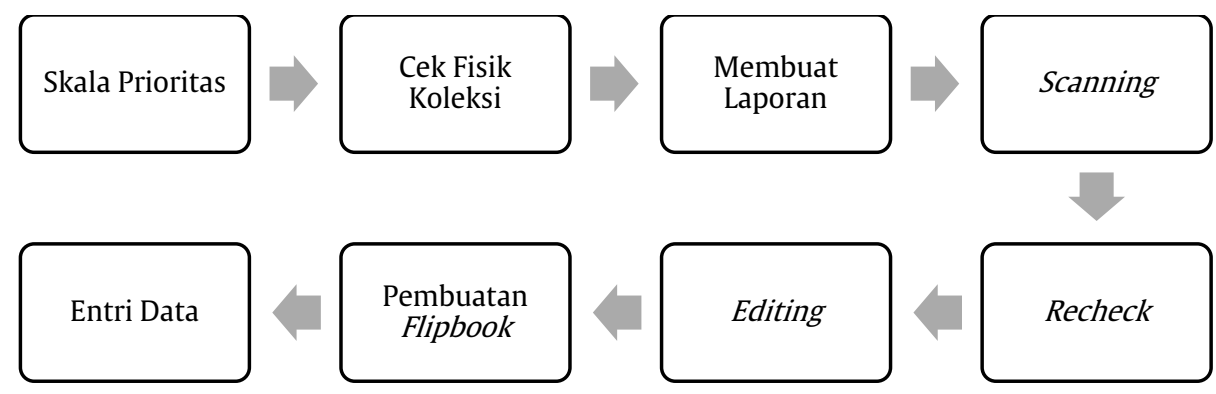

Gambar 3. Tahapan Proses Digitalisasi Koleksi Buku Langka di Dinas Kearsipan dan Perpustakaan Kabupaten Banjarnegara

Proses digitalisasi koleksi buku langka di Dinas Kearsipan dan Perpustakaan Kabupaten Banjarnegara dilaksanakan dengan tahapan ditunjukkan pada Gambar 3. Langkah awal digitalisasi yaitu menentukan koleksi buku langka mana yang akan diprioritaskan untuk dilakukan alih media. Koleksi yang diutamakan adalah koleksi dengan kondisi fisik yang mulai rapuh dan memiliki nilai informasi yang tinggi, mengandung khasanah budaya 
bangsa, sudah tidak diterbitkan lagi di pasaran dan jumlahnya terbatas. Setelah menentukan koleksi buku yang akan dilakukan digitalisasi, langkah selanjutnya adalah melakukan pengecekan kondisi fisik apakah ada halaman yang hilang, sobek atau bahkan tulisan sudah pudar. Jika koleksi sudah sangat rapuh maka menggunakan scanner overhead untuk menghindari kerusakan yang lebih parah. Untuk koleksi yang masih baik bisa menggunakan scanner tipe flatbed.

Kemudian membuat laporan koleksi yang akan didigitalisasi yang memuat judul, nama pengarang, tahun terbit, penerbit, ISBN (jika ada), kondisi fisik koleksi sebelum dilakukan digitalisasi dan kondisi fisik setelah dilakukan digitalisasi. Laporan ini juga berguna untuk mengetahui koleksi mana saja yang sudah dilakukan digitalisasi. Selanjutnya melakukan scanning koleksi buku langka menggunakan sebuah alat scanner. Kegiatan scanning dilakukan dengan cara membuka setiap halaman buku langka sampai selesai kemudian menyimpannya dalam bentuk file PDF pada database komputer. File disimpan di dalam satu folder yang sama untuk setiap judul koleksi. Resolusi dalam setiap penyimpanan gambar adalah 300 dpi. Canon CanoScan LiDE 120 juga memiliki teknologi jenis CIS (Contact Imaging Sensor) dan OCR (Optical Character Recognition) yang mampu menghasilkan warna yang lebih sempurna.

Hasil scanning koleksi yang sudah masuk ke database dalam bentuk PDF dilakukan pengecekan kembali untuk melihat apakah ada halaman yang terlewat atau tidak, apakah ada halaman yang miring, apakah ada halaman yang tidak jelas hasilnya dan apakah ada halaman yang terpotong pada saat proses scanning. Jika terdapat kekurangan maka dicatat pada buku dan dilakukan scanning ulang pada halaman tersebut sampai menghasilkan hasil scanning yang terbaik. Setelah jumlah halaman lengkap, langkah selanjutnya mengedit serta memperbaiki file hasil scanning dengan menggunakan aplikasi Nitro Pro 9. Ada beberapa kegiatan dalam editing file hasil scanning, antara lain menggabungkan file hasil scanning per halaman menjadi satu file dan pemberian watermark bertuliskan "Disarpus Kab. Banjarnegara" berwarna putih dengan rotation-53 dan opacity 40 sebagai bukti identitas kepemilikan.

Setelah proses pembuatan watermark, selanjutnya dilakukan pembuatan flipbook menggunakan aplikasi 3D Page Flip Standard (lihat Gambar 4). Cara pembuatan flipbook di Dinas Kearsipan dan Perpustakaan Kabupaten Banjarnegara mengikuti alur sesuai Gambar 5.

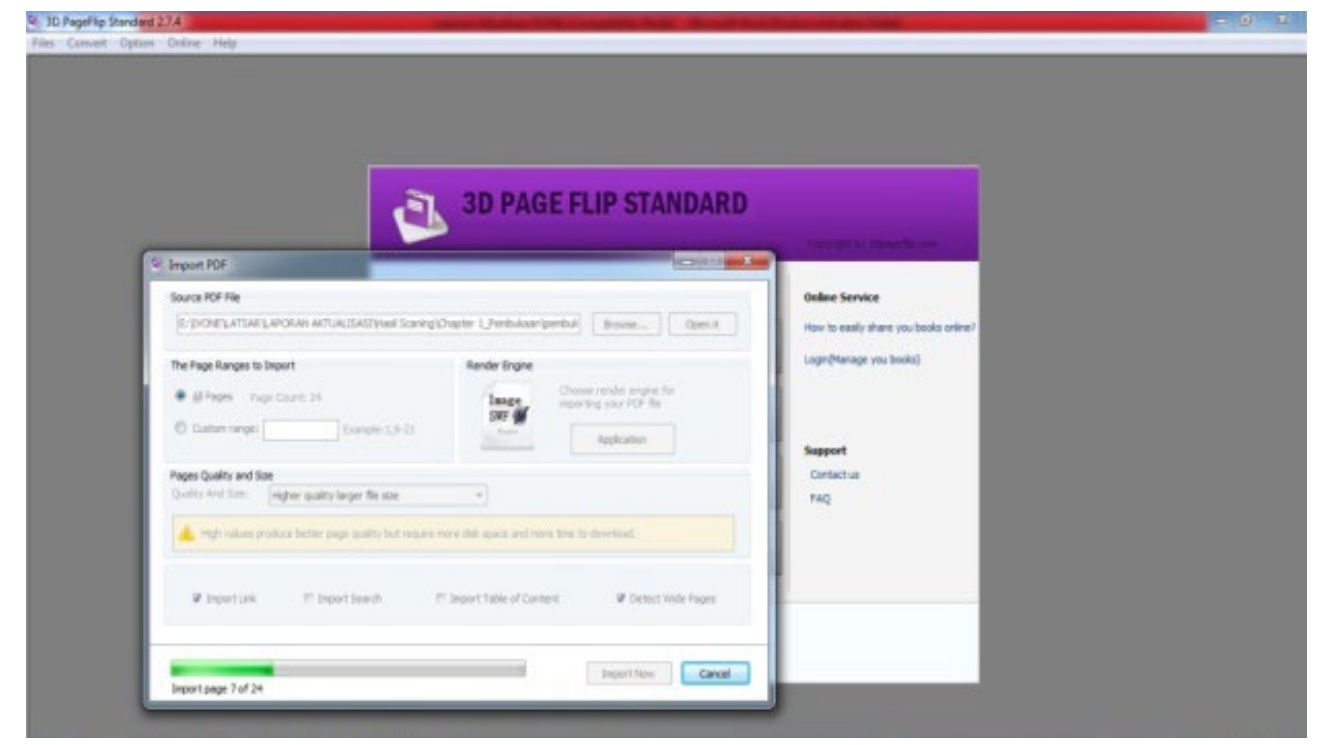

Gambar 4. Pembuatan flipbook menggunakan aplikasi 3D Page Flip Standard 


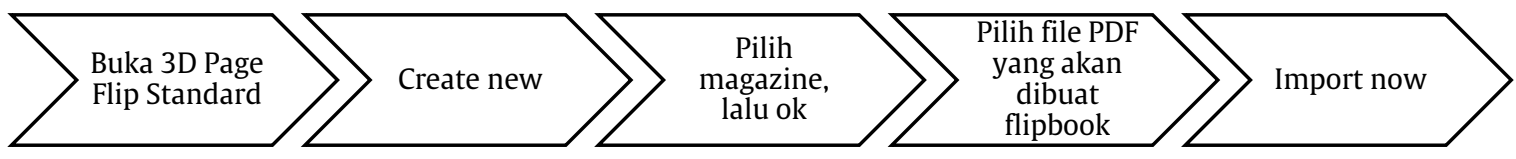

Gambar 5. Alur Pembuatan Flipbook dengan aplikasi 3D Page Flip Standard

Setelah flipbook koleksi buku langka sudah jadi (lihat Gambar 6), langkah selanjutnya yaitu entry data bibliografi pada aplikasi INLISLite. Aplikasi INLISLite yang bisa mendukung koleksi digital dalam bentuk flipbookyang digunakan di Dinas Kearsipan dan Perpustakaan Kabupaten Banjarnegara adalah INLISLite versi 3.1. Kemudian mengupload flipbook pada konten digital aplikasi INLISLite versi 3.1 (lihat Gambar 7).

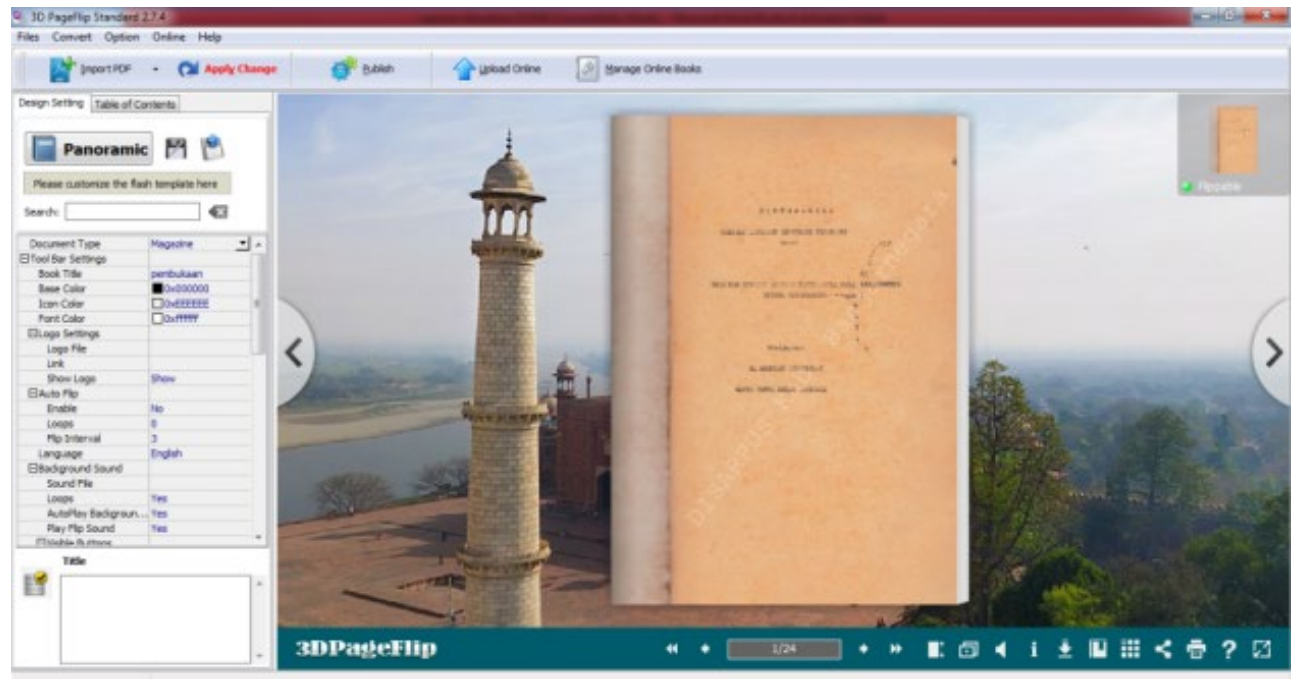

Gambar 6. Hasil pembuatan flipbook

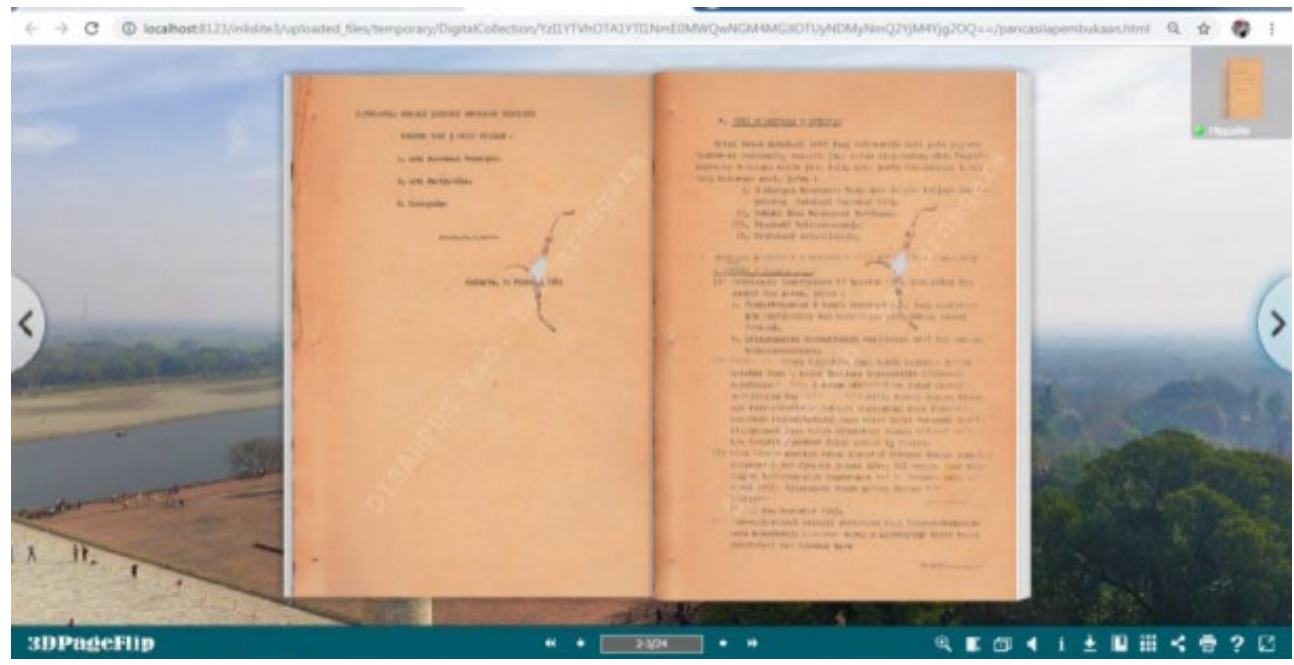

Gambar 7. Tampilan flipbook pada aplikasi INLISLite Versi 3.1

Proses digitalisasi koleksi langka di Dinas Kearsipan dan Perpustakaan Kabupaten Banjarnegara telah menghasilkan terobosan baru yakni koleksi elektronik berbasis flipbook. Terobosan ini diharapkan dapat menunjang pemustaka yang tidak lagi melihat fisik koleksi langka yang rawan kerusakan maupun sinopsisnya saja, namun pemustaka juga bisa mendapatkan isi koleksi langka dengan perpaduan animasi dari flipbook yang 
cukup menarik dan tentunya aman bagi pelestarian, seperti kutipan wawancara pemustaka “...merasa senang dan puas bisa mengetahui isi full-text koleksi buku langka yang dimiliki DISARPUS meskipun tidak membuka bukunya secara langsung”.

\subsection{Kendala Proses Digitalisasi Koleksi Buku Langka}

Ada beberapa kendala yang muncul selama proses digitalisasi koleksi buku langka di Dinas Kearsipan dan Perpustakaan Kabupaten Banjarnegara, yaitu: (1) pedoman standar teknis atau SOP; (2) sarana dan prasarana; (3) sumber daya manusia; dan (4) anggaran. Pustakawan kesulitan dalam melakukan kegiatan digitalisasi koleksi karena belum adanya regulasi yang jelas dan tertulis berupa Surat Keputusan Kepala Dinas atau standar teknis yang memuat bagaimana kriteria koleksi, prosedur digitalisasi, serta alur proses digitalisasi. Pedoman standar atau SOP seharusnya bisa segera dibuat karena dengan adanya standar yang jelas mengenai digitalisasi koleksi maka akan menghasilkan kinerja dan hasil yang jelas serta tersusun.

Fasilitas digitalisasi juga kurang memadai dalam proses digitalisasi koleksi buku langka di Dinas Kearsipan dan Perpustakaan Kabupaten Banjarnegara, seperti alat scanner yang sesuai dengan kondisi fisik buku langka yang sudah rapuh. Dinas Kearsipan dan Perpustakaan Kabupaten Banjarnegara memiliki alat scanner tipe overhead yang berada di bidang kearsipan dan scanner tipe flatbed yang berada di bidang perpustakaan. Kemudian belum adanya komputer khusus yang digunakan sebagai database koleksi buku langka dan komputer untuk melayankan koleksi buku langka dalam bentuk digital berupa flipbook. Layanan untuk koleksi buku langka dalam bentuk digital sebaiknya menggunakan komputer khusus bukan menggunakan komputer $O P A C$.

Selain itu, pustakawan atau petugas perpustakaan yang menguasai digitalisasi koleksi juga belum ada, sehingga kegiatan digitalisasi yang dilakukan berdasarkan pengalaman dari seorang pustakawan yang sebelumnya pernah melakukan kegiatan digitalisasi. Perlu diadakan pelatihan bagi pustakawan maupun tenaga perpustakaan untuk meningkatkan kompetensi mereka di bidang digitalisasi sehingga akan meningkatkan kemampuan dan menghasilkan koleksi digital yang lebih bagus dan inovatif. Kegiatan digitalisasi di Dinas Kearsipan dan Perpustakaan Kabupaten Banjarnegara berjalan dengan sarana dan prasarana yang dimiliki seadanya. Pelaksanaan digitalisasi menggunakan scanner serta komputer yang sudah ada dan bukan secara khusus diadakan untuk kegiatan digitalisasi, sehingga sarana dan prasarana yang seadanya tersebut menjadi rawan terhadap virus dan kerusakan sistem lainnya.

\section{Kesimpulan}

Koleksi digital merupakan suatu bentuk transformasi informasi yang memudahkan pemustaka dalam mengakses sebuah koleksi yang dimiliki perpustakaan. Perpustakaan harus selalu melakukan inovasi guna memberikan pelayanan yang terbaik untuk pemustaka dan mendorong literasi informasi masyarakat pada umumnya. Salah satu inovasi yang dikembangkan oleh Dinas Kearsipan dan Perpustakaan Kabupaten Banjarnegara adalah digitalisasi koleksi buku langka dalam bentuk flipbook. Digitalisasi koleksi ini menyajikan koleksi buku langka yang sudah diubah bentuk menjadi flipbook atau buku digital yang bisa diakses pada aplikasi INLISLite versi 3.1, sehingga pemustaka bisa mengakses full-text isi koleksi buku langka tersebut. Walaupun terdapat beberapa kendala dalam digitalisasi, namun preservasi koleksi dengan cara mengalih bentuk adalah pelestarian yang paling dibutuhkan perpustakaan dan pemustaka saat ini dan menjadi 
alternatif preservasi sekaligus pemberdayaan koleksi langka yang lebih aman dan menarik.

Daftar Pustaka

Andina, E. (2011). BUKU DIGITAL DAN PENGATURANNYA. Aspirasi: Jurnal Masalahmasalah Sosial, 2(1), 79-95. https://doi.org/10.46807/ASPIRASI.V2I1.429

Asaniyah, N. (2017). Pelestarian Informasi Koleksi Langka. Digitalisasi, Restorasi, Fumigasi. Buletin Perpustakaan. Buletin Perpustakaan, 57Juni), 85-94.

Departemen Pendidikan Nasional. (2014). Kamus Besar Bahasa Indonesia. Balai Pustaka.

Fadhlullah, M. F., \& Christiani, L. (2019). Analisis Kegiatan Alih Media Digital Sebagai Upaya Pelestarian Koleksi Local Content Di UPT Perpustakaan Proklamator Bung Hatta. Jurnal IImu Perpustakaan, 63), 681-690.

Hs., L. (2009). Manajemen Perpustakaan. Pinus.

Martoatmodjo, K. (2013). Pelestarian Bahan Pustaka. Universitas Terbuka.

Perpustakaan Nasional RI. (2014). Pedoman Pembuatan E-Book dan Standar Alih Media. Perpustakaan Nasional RI. (2019). Peraturan Perpustakaan Nasional Republik Indonesia Nomor 2 Tahun 2019.

Prabowo, A., \& Heriyanto. (2013). Analisis Pemanfaatan Buku Elektronik ( E-Book ) Oleh Pemustaka di Perpustakaan SMA Negeri 1 Semarang. Jurnal IImu Perpustakaan, 2, 1 9.

Putranto, M. T. D., \& Husna, J. (2015). “Proses Digitalisasi Koleksi Deposit Di UPT Perpustakaan Daerah Jawa Tengah.” IImu Perpustakaan, 4(3), 2. https://ejournal3.undip.ac.id/index.php/jip/article/view/9736

Undang-Undang Republik Indonesia No 28 Tahun 2014 tentang Hak Cipta, Pub. L. No. 28 (2014). https://peraturan.bpk.go.id/Home/Details/38690

Riyanto, Lukman, \& Subagyo. (2012). Pengembangan digital library local contentpekalongan dalam format buku 3 dimensi. Jurnal LIPI, 1(1), 1-13.

Saleh, A. R. (2013). Pengembangan Perpustakaan Digital(2 ed.). Rumah Q-ta Production. https://www.researchgate.net/profile/AbdulSaleh/publication/303805197_Pengembangan_perpustakaan_digital_teori_dan_prak tik_tahap_demi_tahap/links/5753bdbe08ae17e65ec6d325/Pengembanganperpustakaan-digital-teori-dan-praktik-tahap-demi-tahap.pdf

Sugianto, D., Abdullah, A. G., Elvyanti, S., \& Muladi, Y. (2013). Modul Virtual: Multimedia Flip Book Dasar Teknik Digital. Jurnal INVOTEC, 6, 101-116.

Sulistyo-Basuki. (2006). Metode Penelitian. Wedatama Widya Sastra.

Sulistyo-Basuki. (1991). Pengantar ilmu perpustakaan. In Gramedia Pustaka Utama. Gramedia Pustaka Utama. https://doi.org/10.1145/3132847.3132886

Surachman, A. (2007). Membangun Koleksi Digital.

Susilana, R., \& Riyana, C. (2008). Media Pembelajaran: Hakikat, Pengembangan, Pemanfaatan, dan Penilaian. Wacana Prima.

Ulandari, Ariyati, E., \& Titin. (2018). Pengaruh Flash Flipbook terhadap Hasil Belajar Siswa di SMP Negeri 11 Pontianak. Jurnal Pendidikan Dan Pembelajaran Khatulistiwa, 712), 1-10. 